\title{
INFLUENCE OF SOME PLANT EXTRACTS ON CERTAIN BIOLOGICAL ASPECTS OF SESAMIA CRETICA LED. UNDER LABORATORY CONDITIONS
}

\author{
AMANY S. EL-HEFNY AND SH.S. YACOUB
}

Plant Protection Research Institute, ARC, Dokki, Giza

(Manuscript received 2 November 2009)

\begin{abstract}
The influence of some plant extracts belonging to different families using different polarity solvents on certain biological aspects of $2^{\text {nd }}$ larval instar of $S$. cretica larvae was investigated under laboratory conditions of $31^{\circ} \mathrm{C} \& 60$ R.H.. The extracted plants were tooth pick, Ammi visnaga Lam (Family: Umbelliferae), coffee tree, Coffea arabica (L. Rubiaceae), pomegranate Punica granalum L. (Punicaceae) and taro Arum colocasia (Araceae). Data obtained showed that acetone pomegranate extract and hexan tooth pick extract caused the highest mortality percentage $(88 \%$ \& $85 \%$ than control). In addition, acetone coffee, acetone pomegranate and hexan tooth pick extracts caused shorter mean of larval duration, 22, 22 and 23 days, respectively. The shortest pupal duration 7 days was due to hexan tooth pick and acetone coffee extract treatments. While the shortest adult longevity ( 8 days) due to the treatment of hexan tooth pick extract. Also, some deformations were found in $S$. cretica larvae and pupae as a result of treatment with acetone coffee extract (30 and 33\%, respectively). The composition of the tested plants were obtained from some scientific sites on the wide world web.

From the previous results, it could be concluded that plant extracts proved to be a safe alternative pest control trend rather than tradional pesticides.
\end{abstract}

\section{INTRODUCTION}

Maize (Zea mays L.)is one of the most important grain crops in Egypt, as it conforms to wheat in its economic importance. It plays, also an important role in several industries important to Egypt's economy as corn oil, fructose sugar and starch production. The use of natural products from plant origin is a new trend which may proof efficient for pests' control. In order to avoid the hazards caused to the environment due to the repeated use of conventional chemical insecticides that are commonly used for corn borers control (Tawfik et al. 1974 and Hiremath et al. 1997).

The Pink stem borer, Sesamia cretica Led. (Lepidoptera, Noctuidae) is destructive to corn crop in Egypt it attacks corn plants which define as the king of the cereal crops not only in Egypt but also all over the world (Abul Nasar, et al., 1968).

The use of natural products from plant origin is new trend which may proof efficient for pests control, on one hand, and to preserve the environment from 
contamination with harmful toxicants, on the other hand these natural products are mainly plant extracts which prove to have deleterious effects on target insect in several ways (Zhao, et al., 1998).

The composition of the tested plants were obtained from some scientific sites on the wide world web.

\section{MATERIALS AND METHODS}

\section{Insects}

The tested insects were collected from the Farm of Agriculture Faculty, Benha University at Moshtohor and reared on pieces of tender parts of maize plant stem under conditions of $31(29-33){ }^{\circ} \mathrm{C}$ and $60(55-65) \%$ R.H iside incubator.

\section{Extracts preparation}

Four plants from different families were chosen in the present experiments to study the influence of their toxic activity on $S$. cretica biology.

The scientific \& english names and the used parts of the plants are shown in the following table.

\begin{tabular}{|l|l|l|l|}
\hline Scientific name & \multicolumn{1}{|c|}{ Family } & \multicolumn{1}{|c|}{ English name } & \multicolumn{1}{c|}{ used part } \\
\hline 1. Ammi visnaga Lam & Umbelliferae & Tooth pick & flower \\
\hline 2. Coffea Arabica L. & Rubiaceae & Coffee tree & Granules of seeds \\
\hline 3. Punica granalum L. & Punicaceae & Pomegranate & shell \\
\hline 4. Arum colocasia & Araceae & Taro & peel \\
\hline
\end{tabular}

All plants were left to dry in the laboratory. Dried parts from the last plants were grained in high speed electric blender Afifi et al., 1988 and Yacoub, 2006. The dried powder were mixed with different polaritic solvents (Hexan, methanol, acetone and water) at ratio $1 \mathrm{gm}$ powder : $2 \mathrm{~cm}^{3}$ solvent, and were blended in blender for 15 minutes then filtered.

The obtained solutions were freezed at $-5^{\circ} \mathrm{C}$ until used. The solvent was evaporated by using electric fan. A volume of $500 \mathrm{ml}$ water was mixed with the residue of the dried extract after adding emulsifier to obtain emulsion of the desired extract $10 \%$ W/V, Sadek (2003).

3- Laboratory experiments

Laboratory experiments were carried out to study the influence of the previously mentioned extracts as toxic activity against 4th instar of S. cretica larvae in the laboratory ( $31^{\circ} \mathrm{C} \& 60 \%$ R.H.), the experiments were carried out by using dipping method. The tender pieces of maize stem were dipped for 10 seconds in the extracted 
solutions, the treated pieces were left in shad to be air dried. Fourty larvae were kept in plastic cups and divided into 4 replicates of 10 larvae per each replicate.

Larval mortality were daily inspected until pupation by using formula:

$\%$ Mortality $=$ No. of dead larvae $\times 100$

Total No. of larvae

Larval, pupal duration, and adults longevity (days) were calculated. Also, percentages larval, pupal malformations were estimated.

\section{RESULTS AND DISCUSSION}

\section{Percentages mortality}

Data presented in Table (1), showed the higher mortality percentage of $2^{\text {nd }}$ instar larvae of $S$. cretica was due to using of acetone as a solvent for each of coffee granules, pomegranate and colocasia extracts achieving, 90, 88 and 69\% mortality, respectively. While, in case of hexan tooth pick extract the mortality was $85 \%$ being the highest of all the remaining solvents.

On the contrary, water tooth pick and granules coffee extracts, also hexan pomegranate extracts and methanol colocasia extracts caused the least percentage mortality (50, 45, 45 and $48 \%$, respectively).

The remaining treatments had intermediate effect ranged from 48 to $70 \%$ mortality resulting from methanol coffee granules and pomegranate extracts, respectively than control treatment which caused $8 \%$ mortality.

\section{2 . Larval duration}

As shown in table (1), all treatments caused significant shortage in larval duration when compared with that of the control (32 days). The shortest larval duration period (22 days) resulted from acetone coffee granules and acetone dry roman shell extracts. However hexan tooth pick extracts, resulted in a relatively short larval duration ( 23 days). The remaining treatments shortened the larval duration in which methanol pomegranate extract achieved (27 days), water colocasia \& coffee granule and hexan pomegranate extracts caused (31 days).

\section{3 . Pupal duration}

All treatments significantly shortened the pupal duration (Table 1). The treatments could be classified in two groups, the first had the shortest period of all extracts, including hexan tooth pick, acetone coffee extract, acetone pomegranate and acetone colocasia extracts achieving 7, 7, 6.5, 8.5 days, respectively. While, the second group included the remaining treatments which caused different pupal duration ranging from 9 to 11 days, attending the least effect level when compared with the control which recorded 12 days, as pupal duration. 


\section{Adult longevity}

All treatments caused significant reduction in adult longevity. The shortest one resulted from acetone granule coffee extract and hexan tooth pick extract being 7.5 and 8 days, respectively when compared with control (12 days). While, the remaining treatments ranged from 9 days (after treatment with hexan, \& methanol coffee granules and methanol \& acetone pomegranate extracts) to 11.5 days after water colocasia extract treatment as shown in Table (1).

\section{5 . Larval malformation}

As shown in table (1 ) the highest percentage of malformed larvae (30\%) resulted from acetone coffee granules extract followed, insignificantly by hexan tooth pick extract (27\%) and acetone pomegranate extract (23\%), respectively, accordingly these extracts may be higher influence on the larvae of $\mathrm{S}$. cretica. On the contrary, the lowest percentage of malformed larvae $(8 \%)$ resulted from treatment by water colocasia extract. While, the remaining treatments could be classified into two groups, the first had intermediate effect $(19,17,15,13$ and 13\%) larval malformation and insignificantly among each other, in the same time they were significantly comparing with the control, These percentages of larval malformation were recorded when the larvae were treated with hexan granule coffee extract, acetone colocasia extract, methanol pomegranate extract, methanol tooth pick extract and water pomegranate extract, respectively. The second group had the least influence on larvae and it included water colocasia, water tooth pick, hexan colocasia, methanol granule coffee, hexan pomegranate and methanol colocasia extracts causing $(8,9,10,10,11$ and $11 \%)$ malformation and they were insignificantly with the control.

Malformations which were detected between the inspected larvae may be described as some destruction at abdomen and thorax region also moulting integument remain and moulting failure.

\section{Pupal malformation}

Data in Table (1) show that there are insignificant increases in the percentage of malformed pupae than control $(6 \%)$ which occurred after methanol and water tooth pick, granules of coffee, and colocasia extracts also hexan and water pomegranate and hexan colocasia extracts, respectively. Treatments caused high significant deformations in the developed pupae were that of acetone coffee granules and hexan tooth pick extracts achieving 33 and $30 \%$ malformation, respectively.

The remaining treatments caused significant pupal malformation and could be fairly arranged ascendingly as follows: acetone colocasia extract (18\%), hexan coffee granules extract (19\%) acetone tooth pick extract (19\%), methanol and acetone pomegranate extracts 21 and $25 \%$, respectively). 
Malformed pupae showed indentations at the ventral side. Also, blackish coloured in head regions and malformation at the former regions. Exuviae of larvae remaining in end of the abdominal region

The chemical components of tested plants

\section{Ammi visnaga Lam}

Its chemical component are

- Terpenes

- Terpene alcohols (bornol, linalol)

- Coumarin and related compounds

\section{Coffea arabica L.}

It contains caffeic acid, caffeine (1,3,7-trimethyl-xanthine), chlorogenic acid, eugenol, niacin, scopoletin, tannin,theobromine, tannic acid and theophylline, propanol, valerianic aldehyde, acetaldehyde and butanal Schultes and Raffauf (1990), Hazenfratz, (1991)

\section{Punica granalum L.}

Ten compounds were isolated and elucidated as: gallic acid (1), methyl gallate (2), ellagic acid (3), (+) catechin (4), isoquerecitrin (5), D-mannitol (6), ursolic acid (7), Oleanolic acid (8), beta-Sitosterol (9) and Daucosterol (10). Lei , et al., (2003).

\section{Arum colocasia}

In addition to its acrid principle it contains a large proportion of starch, also, gum, albumen, saccharine matter, calcium and potassium salts, and extractive. When the acrid property is driven off by heat, the root yields a pure, delicate, amylaceous matter, resembling the finest arrowroot, very white and nutritive. That raphides of oxalate of calcium give to the corm its acridity has been asserted by Weber (1891).

The results obtained in this study are in agreement with that of Lamiri (2001) in which they found that essential oils from Ammi visnaga had an efficient against Hessian fly (Cecidomiidae) in Morocco. Also, Mohamed and Abd El-Aziz (2005) stated that tooth pick extract had an insecticidal activity against compea beetle (Callasobruchus maculates) in Egypt. While, Morsy et al. (1998) showed that acetone and methanol pomegranate extract had larvicidal activity against Chrysomyia albiceps in Egypt.

Magalhaes et al (2008), in Brazil, stated the phenolics chlorogenic, caffeic acids and the alkaloid caffeine were found in coffee leaves inhibiting effect on egg-laying by the coffee leaf miner Leucoptera coffeella. 
The pervious results are considered very important to clarify the influence of plant extracts in the integrated pest control against numerous of insects without any environmental pollution or using chemical pesticides.

Table 1. Effect of four plant extracts on some biological aspects of S. cretica $4^{\text {th }}$ instar larvae.

\begin{tabular}{|c|c|c|c|c|c|c|c|}
\hline Treatments & solvent & $\begin{array}{c}\text { Mortality } \\
(\%)\end{array}$ & $\begin{array}{l}\text { Larval } \\
\text { duration } \\
\text { (day) }\end{array}$ & $\begin{array}{l}\text { Pupal } \\
\text { duration } \\
\text { (day) }\end{array}$ & $\begin{array}{c}\text { Larval } \\
\text { malformation } \\
\%\end{array}$ & $\begin{array}{l}\text { Pupal } \\
\text { malfor } \\
\text { mation } \\
\%\end{array}$ & $\begin{array}{c}\text { Adult } \\
\text { longevity } \\
\text { (day) }\end{array}$ \\
\hline \multirow{4}{*}{ Tooth pick } & Hexan & 85 & 23 & 7 & 27 & 30 & 8 \\
\hline & Methanol & 50 & 29 & 9.5 & 13 & 15 & 10.5 \\
\hline & Acetone & 63 & 28 & 8 & 19 & 19 & 9.5 \\
\hline & Water & 50 & 30 & 9 & 9 & 11 & 10 \\
\hline \multirow{4}{*}{ Coffee granules } & Hexan & 55 & 30.5 & 10.5 & 19 & 19 & 9 \\
\hline & Methanol & 48 & 28.5 & 9 & 10 & 15 & 9 \\
\hline & Acetone & 90 & 22 & 7 & 30 & 33 & 7.5 \\
\hline & Water & 45 & 31 & 10 & 9 & 13 & 10.5 \\
\hline \multirow{4}{*}{ Pomegrante } & Hexan & 45 & 31 & 10 & 11 & 10 & 11 \\
\hline & Methanol & 70 & 27 & 7.5 & 15 & 21 & 9 \\
\hline & Acetone & 88 & 22 & 6.5 & 23 & 25 & 9 \\
\hline & Water & 62 & 30 & 8.5 & 13 & 15 & 10 \\
\hline \multirow{4}{*}{ Taro } & Hexan & 58 & 29 & 9.5 & 10 & 14 & 11 \\
\hline & Methanol & 48 & 30 & 10 & 11 & 10 & 10.5 \\
\hline & Acetone & 69 & 27 & 8.5 & 17 & 18 & 9.5 \\
\hline & Water & 49 & 31 & 11 & 8 & 10 & 11.5 \\
\hline Control & - & 8 & 32 & 12 & 4 & 6 & 12 \\
\hline$F$ value & _ & _ & 15.87 & 13.9 & 14.02 & 9.55 & 14.23 \\
\hline LSD & & _ & 2.91 & 1.53 & 7.12 & 8.43 & 1.23 \\
\hline
\end{tabular}




\section{REFERENCES}

1. Abul-Nasr, S.E., A.K.M. El-Nohal and S.K. Shahoudah. 1968. Some biological aspects of the corn stem borer, Sesamia cretica Led. Bull. Ent. Soc. Egypt, 52: 429 $-444$.

2. Afifi, F.A., A.M. Hekal and M. Salem. 1988. Fenugreek seed extract as protectants of wheat grain against certain strored product insects. Annals of Agric. Sci., Fac. Agric., Ain Shams Univ., Cairo, Egypt, 33(2): 1331 - 1344.

3. Hazenfratz, M. 1991. Human Psychopharmacology book Ian Hindmarche (Editor)

4. Hiremath, I.G., Y.J. Ahn, S.I. Kim. 1997. Insecticidal activity of Indian plant extracts against Nilaparvata lugens (Homoptera: Delphacidae) Appl. Entomol. Zool. 32: $159-166$.

5. Lamiri, M.N. 2001. Kurt Schnaubelt details a treatment plan for Asthmatic conditions in his Advanced Aromatherapy book 2138 Humbold, Bellingham (Editor).

6. Lei F, DM Xing, L. Xiang, Y.N. Zhao, W. Wang, L.J. Zhang and L.J.Du. 2003. J Chromatogr B Analyt Technol Biomed Life Sci. 25,796(1): 94-. 189.

7. Magalhães, S.T.V., R.N.C. Guedes, A.J. Demuner and E.R. Lima. 2008. Effect of caffeine on egg laying of leaf minor Leucoptera coffeella. Ph.D. Departamento de Biologia Animal, Universidade Federal de Viçosa, Viçosa, Brazil

8. Mohamed, R.A. and A.E. Abd EL-Aziz. 2005. The insecticidal activity of Tooth- pic seed (Ammi Visnaga) extracts against compea beetle (Callasobruchus maculates) Agric. Res. Rev (In Press) 146.

9. Morsy TA, S.A. Mazyad , I.M. El-Sharkawy. 1998. The larvicidal activity of solvent extracts of three medicinal plants against third instar larvae of Chrysomyia albiceps. J Egypt Soc Parasitol. , 28(3):699-709.

10. Sadek, M., M. 2003. Antifeedant and toxic activity of Adhatoda vasica leaf extract against Spodoptera littoralis (lep. Noctuidae) . Appl. Ent. 127(1): 396 - 404.

11. Schultes, R. E and R. F. Raffauf. 1990. Human Psychopharmacology book Ian Hindmarche (Editor).

12. Tawfik, M.F.S., M.T. Kira and S.M.I. Metwally. 1974. On the abundance of major pests and their associated predators in corn plantations. Bull. Soc. Ent. Egypt, 58, pp. $167-177$. 
13. Yacoub, Sh. S. 2006. Efficacy of some plant extracts in controlling Sesamia cretica Led. and Ostrinia nubilalis (Hubn.) in maize fields. Ph. D Thesis, Fac of Agric., Benha University, Egypt.

14. Zhao, B., G.G.Grant, D.Langevin, L. MacDonald. 1998. Deterring inhibiting effects of quinolizidine alkolides on spruce budworm (Lepidoptera: Tortricidae) oviposition. Environ. Entomol. 27, $984-992$. 
تأثير بعض المستخلصات النباتية والمبيدات على بعض النواحى البيولوجية لحشرة دودة القصب الكبيرة تحت الظروف المعملية

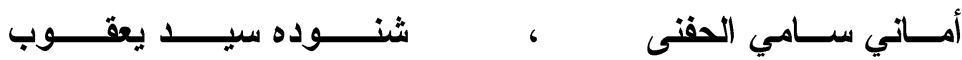

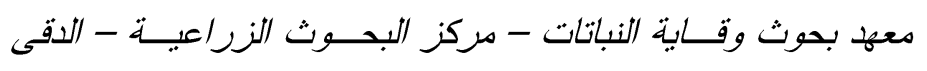

تم دراسة تأثير أربعة مستخلصات النباتية - تتبع عائلات مختلفة - باستخدام مذيبات عضوبة مختلفة القطبية على بعض النواحى الحيوية على العمر اليرقى الثانى لحشرة دودة القصب الكبيرة.

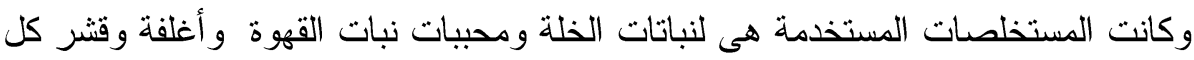
من الرمان والقلقاس على التو الى. أظهرت النتائج ان مستخلص الرمان بالاتسيتون و الخلة بالهكسان

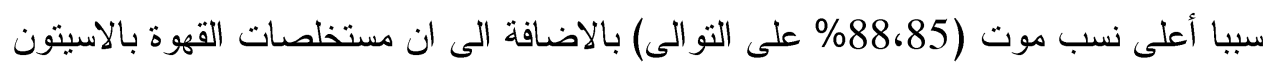

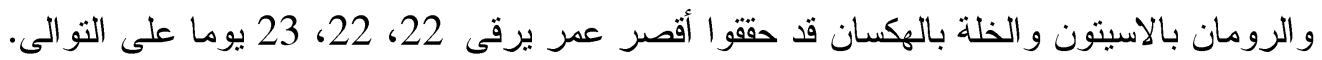
وكان أقصر عمر عدرى هو 7 أيام كنتيجة للمعاملة بمستخلصات الخلة بالهكسان ومستخلص القان القهوة بالاسيتون 30، 33\% على التو الى. مكونات النباتات تم الحصول عليها من بعض الموان اقع العلمية من

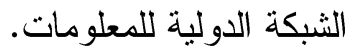
من النتائج السابقة يمكن الاشارة الى ان المستخلصات النباتية قد أثتتت انها بديل امن فى مجال مكافحة الآفات بخلاف المبيدات النقليدية. 